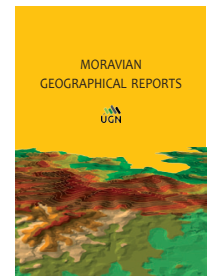

MORAVIAN GEOGRAPHICAL REPORTS

\title{
How distance influences dislike: Responses to proposed fracking in Fermanagh, Northern Ireland
}

\author{
Kerrie CRAIG ${ }^{\mathrm{a}, \mathrm{b}}$, Darrick EVENSEN ${ }^{\mathrm{c}}$, Dan VAN DER HORST ${ }^{\mathrm{a}, \mathrm{d}}$ *
}

\begin{abstract}
Despite extensive social science research into public perceptions and social responses to fracking, scholars have only begun to examine the relationship between distance to development and support or opposition for it. Importantly, the emerging studies are exclusively from the United States, and focus on communities and regions in which fracking already exists - in contrast to areas where it is proposed and still going through planning approvals. This paper reports public responses to proposed fracking in County Fermanagh, Northern Ireland, United Kingdom. A total of 120 people participated in an in-person survey with a qualitative followup in four locations: the village right next to the development site, two other villages just inside and just outside the wider fracking concession area, and in the capital city of Belfast, $150 \mathrm{~km}$ away. A clear spatial pattern of opinion was found, from almost universal opposition to fracking next to the site, to an even threeway split between proponents, opponents and 'neutrals' to fracking in general, in Belfast. Results show that some risks are perceived to be more local than others, whilst perceived (economic) benefits are recognised mainly at the national level. Content analysis of local and national newspapers revealed a very clear and similar pattern. Connections to Fermanagh, through visits or long-term residence, were also clear predictors of opposition to fracking. The spatial pattern of support for fracking in Northern Ireland differs substantially from each of the contrasting patterns observed in the United States. We discuss likely reasons for this and implications for both research and policy.
\end{abstract}

Keywords: hydraulic fracturing; public acceptance; construal level; psychological distance

Article history: Received 20 May 2019, Accepted 25 June 2019, Published 30 June 2019

\section{Introduction}

Hydraulic fracturing ('Fracking') is an established method of fossil fuel extraction in the US (Jacquet et al., 2018, Haggerty et al., 2018, Theodori, 2018), Australia (Luke et al., 2018a), Canada (Lachapelle et al., 2018), and China (Tan et al., 2019), with many other countries hoping for this technology to reverse their dependence on imported fossil fuels and provide welcome extra cash for the state coffers. Nevertheless, fracking is also characterised by a polarisation of views and there is substantial concern and debate surrounding the possible impacts of fracking within the government, media and public sphere (Smith and Ferguson, 2013; Ritchie et al., 2014). Although studies of the relationship between fracking location and public opinion have emerged in the last few years (Alcorn et al., 2017; Boudet et al., 2016; 2018; Clarke et al., 2016, Davis and Fisk, 2014, Evensen and Stedman, 2016; Howell et al., 2017; Junod and Jacquet, 2019; Junod et al., 2018; Mayer, 2016; Zanocco et al., 2019), these all focus on areas in the United States and compare proximity to current shale gas or oil development with areas more distant from development. Construal level theory, a key psychological explanation for the role of distance in shaping perceptions, contends that people only concretely experience things that are psychologically close to them - spatially (geographically), temporally, socially, and hypothetically (real, not abstract) (Trope and Liberman, 2010). No fracking (yet) exists in the entire country of Northern Ireland - indeed, none existed in the wider United Kingdom during our data collection. Therefore, the psychological processes informing

\footnotetext{
${ }^{a}$ School of Geosciences, University of Edinburgh, UK (*corresponding author: D. van der Horst, e-mail: dan.vanderhorst@ed.ac.uk)

${ }^{\mathrm{b}}$ Royal Haskoning DHV Consulting, Edinburgh, UK

${ }^{\mathrm{c}}$ School of Social \& Political Science, University of Edinburgh, UK

${ }^{\mathrm{d}}$ Department of Environmental Geography, Institute of Geonics, The Czech Academy of Sciences, Brno, Czech Republic
} 
construal level (i.e. the abstract or concrete level at which perceptions of fracking are formed) could be quite different in Northern Ireland from that revealed in aforementioned United States research. Furthermore, Alcorn et al. (2017) point to the need for research on the relationship between proximity and attitudes towards fracking to examine different stages of development, and Zanocco et al. (2019) explicitly recommend such research attending to proposed development.

In line with other siting-controversies (Owens, 2004), there are arguments that benefits from fracking seem to be nationwide, yet local communities bear the negative externalities. Research has shown that key environmental risks and health risks associated with fracking tend to be tightly spatially concentrated around drilling sites (Meng, 2015; Meng and Ashby, 2014). Nevertheless, Mayer (2016) demonstrates that perceived proximity to oil/gas development has far greater correlation with risk and benefit perceptions than actual proximity, and Alcorn et al. (2017) reveal support for a moratorium on fracking is much more dependent on perceived proximity than actual distance to the nearest well. Perceived proximity is, therefore, important, but the direction of its influence is less clear; Alcorn et al. (2017) show divergent effects in different US states (increased proximity associating with increased support for a moratorium in Pennsylvania and the opposite in Ohio). Within and across communities and regions, the debate surrounding the distribution of risk and benefits is highly contentious and local opposition is becoming more prevalent, headed by opposition groups and "Fractivists" (Jones et al., 2013; Henderson and DugganHaas, 2014; Taylor, 2014)

In the UK and other EU countries, where fracking has been discussed, planned and sometimes tested but commercial production has not (yet) started, public perception research has largely been limited to general surveys O'Hara et al. $(2012 ; 2014)$ carried out 10 cross-sectional surveys examining public attitudes towards shale gas extraction from March 2012 to September 2014. The results indicated attitudes towards fracking fluctuated across the random samples over time, with the authors implying that well documented protests against fracking in Balcombe, Sussex, played a vital role in influencing people's perceptions towards fracking (O'Hara et al., 2014). The results from these surveys show higher levels of support for fracking (53.6\% in $2012 ; 51 \%$ in 2014) than those found by the Department of Energy and Climate Change in 2014 (24\%) and the European Commission in 2013 (32.5\% in a survey across Poland, France, Romania, Spain and Germany). These last two surveys found only a small percentage difference in levels of support and opposition, which highlights that the public have undecided views concerning shale gas extraction (see also Whitmarsh et al., 2015).

Understanding public perceptions, especially those in nearby communities who may be most directly affected by fracking, will be important to help policy makers and energy companies effectively engage with communities (Clarke et al., 2012). In an effort to shed light on which factors most influence views on proposed fracking in County Fermanagh - the only location to have been seriously considered for fracking in Northern Ireland (first in 2014 and now again today [June 2019]) - we examine the role of socio-demographics, psychological characteristics (including perceived distance), and local and national mass media coverage.

\section{Theoretical background}

\subsection{Place, proximity, and perceptions}

Local opposition to fracking is one of the most significant obstacles to the expansion of shale gas industry in Europe (Cotton, 2013; Luke et al., 2018b; van de Graaf et al., 2018), however comparatively little research has examined how some factors - particularly actual and perceived proximity to development - condition such opposition, which is what this study attempts to address.

Social psychological literature has revealed that the socially-constructed concepts of place identity (Proshansky, 1978; Korpela, 1989) and place attachment (Devine-Wright, 2009; Altman and Low, 1992) can be key determinants of people's perceptions of new developments. Personal experience with an area, either by living there for a long period or visiting the area recreationally, can affect levels of place attachment (Brown and Perkins, 1992; Kyle et al., 2004; Devine-Wright, 2009). Place identity theory explains how people interact and identify themselves with the environment (Wester-Herber, 2004). A new facility can threaten and intrude on people's perception of place, and their own personal identity (van der Horst and Vermeylen, 2012). Place identity, therefore, is important for authorities and locals to discuss in regards to proposed facilities in their area (Woods, 2003).

Henderson and Duggan-Haas (2014) argue that opposition to fracking can be explained as an attempt to ameliorate threats to self-integrity. Similarly, Stedman (2002) notes that people are willing to fight for places that are central to their identity; therefore, high levels of opposition are likely if people identify themselves with a certain place and feel attached to it. This has been observed in numerous studies in relation to fracking, predominantly from the United States, but with some research in Australia (Evensen and Stedman, 2018; Huth et al., 2018; Jacquet, 2014; Jacquet and Stedman, 2014; Lai et al., 2017; Luke et al., 2018b; Perry, 2012; Sangaramoorthy, et al., 2016; Schafft and Biddle, 2015; Willow, 2014; Willow et al., 2014).

Place attachment is the process of attaching oneself to a particular place either due to an emotional bond with the location or the length of dwelling there, and can be at the individual or collective community level (Manzo and Perkins, 2006; Devine-Wright, 2009). The longer someone has lived in an area the more likely they will be attached to a place, and research by Raymond et al. (2010) found significant correlations between place identity and length of residence. Cotton (2013) discusses the shock that individuals experience when shale gas developments are announced which can disrupt an individual's sense of place attachment. Lewicka (2011) suggests collective communal place attachment can help empower communities to oppose change. Junod et al. (2018) link place disruption to proximity to fracking in their research describing a 'Goldilocks Zone' phenomenon - a non-linear relationship between support for fracking and proximity to development - as distance from fracking increases, support first increases and then decreases. The area where fracking is perceived as 'just right' (as in the Goldilocks fairy-tale) is not too close but not too far away from development.

Although the link between place disruption and proximity to development is intuitive, the Goldilocks Zone is not empirically robust; Junod and Jacquet (2019) show that the original findings from the Bakken Shale in the US an area of extremely remote and socially homogenous 
populations - do not systematically replicate in Ohio. Furthermore, Zanocco et al. (2019) find no evidence for a (US) national-level Goldilocks Zone surrounding well sites. Junod and Jacquet (2019) point to differences that likely affect the relationship between proximity to development and support for development, with the following making the Goldilocks Zone less likely: less private mineral rights ownership, greater mix of viable industries locally, higher population density, and increased cultural heterogeneity in communities. Based on these factors, we would expect Northern Ireland not to experience the Goldilocks Zone, and to reveal a more direct relationship between proximity to development and support for fracking.

In the United States, research has shown a direct, positive relationship between proximity to development and support (i.e. closer to development $=$ more support) (Boudet et al., 2018; Gravelle and Lachapelle, 2015; Howell et al., 2017; Junod and Jacquet, 2019; Zanocco et al., 2019). Nevertheless, other research reveals no direct independent effect from geospatial proximity on support for fracking (Alcorn et al., 2017; Boudet et al., 2016; Davis and Fisk, 2014; Mayer, 2016), and Clarke et al. (2016) even provide evidence of a weak but significant inverse relationship (i.e. decreased proximity to development $=$ increase support). Adding further nuance to the relationship in the United States, Evensen and Stedman (2016) note that risks and benefits are more strongly associated with support for fracking in areas closer to well sites than in areas more distant. Similarly, Clarke et al. (2016) reveal a stronger connection between political views and support for fracking in areas farther away from well sites, and Boudet et al. (2018) connect increased geospatial proximity to well sites to greater familiarity with fracking. These last three studies' findings are consistent with construal level theory, mentioned earlier, which predicts that increased distance from something makes ideas of that thing more abstract, and therefore more likely to be associated with general worldviews as opposed to specific concrete beliefs about the thing itself.

A problem with applying construal level theory to Clarke et al.'s (2016), Evensen and Stedman's (2016), and Boudet et al.'s (2018) data is that those data include measures of geospatial proximity, whereas construal level theory speaks to psychological proximity. The two studies that use psychological proximity to predict support for fracking both show psychological proximity as a far stronger determinant of support/opposition than geospatial proximity, but, again, the findings are not consistent with respect to the direction of the effect (Alcorn et al., 2017; Mayer, 2016). In this research, increased psychological proximity associates with support in Ohio, opposition in Colorado and Pennsylvania, and there is no discernible effect in Texas.

In summary, the relationship between proximity (both geospatial and psychological) to fracking and support for fracking is decidedly unclear in the United States. We observe the full range of relationships - direct, inverse, and none. The data suggests that local residents are more aware of fracking and its impacts locally, including risks and benefits, but the valence of those impacts is conditioned by the range of aforementioned factors identified by the scholars working in this area. In our research described below, we examine geospatial and psychological proximity to proposed fracking via the length of time local residents have spent living in County Fermanagh where the Northern Ireland fracking has been proposed (ordinal variable), as well as whether people living outside of Fermanagh have visited the County (dichotomous variable). These are imperfect measures of psychological proximity with room for improvement, but we think they better capture the aforementioned theoretically and empirically manifest connections between place disruption and psychological proximity than the binary measures that were used in the two extant studies on psychological proximity to fracking (i.e., whether people think they live close to fracking or not).

The motivations for public support or opposition are complex, dependent on a person's physical and psychological connection to place, but also contingent on perceptions of fairness and trust (Devine-Wright and Howes, 2010, Cotton 2013).

\subsection{Trust}

Trust is a social construct derived from relationships between various actors and the individual that plays a vital role in influencing perceptions and understanding of new technologies (Mumford and Gray, 2010). Putman (1993, p. 171) states, "trust lubricates cooperation and cooperation builds trust"; therefore, for developers and policy makers to gain trust they must listen to the concerns of local communities and the wider public. Having trust in developers and those in positions of power is important when introducing new technologies as it is trust within the local community that enables shared cognition (Mumford and Gray, 2010).

Flynn and Bellaby (2007) argue that opposition to new technologies is dependent on trust, and levels of trust can moderate the relationship between place attachment and attitudes towards a project (Devine-Wright and Howes, 2010). Gross (2007) found strong correlations between the strength of trust between the community and developers with the degree of acceptance towards the proposed project. This was also found by Upreti and van der Horst (2004), who established that public perceptions of fairness played a crucial role in the development and siting of new energy facilities, and public acceptance or rejection of developments was mainly based on trust.

O'Brien and Hope (2010) and Pijawka and Mushkatel (1991) suggest that high levels of public opposition to new energy developments occur due to the lack of trust created as a result of a top-down approach to policy implementation, and a lack of confidence in local authorities and developers (Rabe and Borick, 2011). A community approach to implementing new technologies will generate greater understanding, support and therefore more trust by the public for the whole process (Aitken, 2010; Walker et al., 2010; Warren and McFadyen, 2010).

\subsection{Role of the Media}

The possibility of shale gas development in the UK has attracted a lot of media attention, and by selecting and presenting certain snippets of information the media can increase public awareness and shape public perceptions of fracking (Ashmoore et al., 2016; Nerb et al., 2001; Davis and Fisk, 2014; Evensen et al., 2014; Hedding, 2017; Jaspal et al., 2014a; Jaspal and Nerlich, 2014; Olive, 2016). Perceptions of fracking are mediated by many sources and a substantial amount of public knowledge about new technologies comes through various forms of media exposure (Nerb et al., 2001; Cox, 2013). Nevertheless, as Boudet et al. (2014) point out, knowledge gained from media coverage of fracking does depend on the characteristics of those engaging with the information. 
Different forms of media coverage can affect the public acceptance of fracking (Boudet et al., 2014). O'Hara et al. (2014) found that in the UK the majority of the public gain their information about fracking from television news. Driediger (2007) claims that television coverage provides more of an emotional setting, rather than informative, in comparison to more analytical newspaper coverage. Ritchie et al. (2014) allege, in the case of fracking, that the media use campaign groups to promote the issue in the public eye and to draw attention to the perceived weaknesses in the policy arrangements, which plays a big part in shaping public perceptions. This is a persistent problem given the increasingly fractured media environment that plays to people's predispositions and vested interests (Henderson and Duggan-Haas, 2014)

There are suggestions that with increasing accessibility to the internet as a source of information on fracking it has a lot of potential for advocacy (Krimsky, 2007) and as it is such a large source of information that provenance and accuracy is often lost, which can shape people's perceptions. Due to various forms of the media influencing people's perceptions of fracking in different ways, it has been recommended that future research should conduct exploratory textual analysis of various media to complement discursive research into psychological factors associated with place and proximity (Dixon and Durrheim, 2000).

In summary, our paper seeks to make the following contributions. Although research has examined the role of geospatial and psychological proximity to fracking, trust, and media use and coverage on support for fracking, no study has yet analysed these key factors in combination. Furthermore, research on these determinants of support for fracking is particularly underdeveloped in Europe where there are various areas (including several in the UK) where fracking has been proposed but where (despite the occasional test drill) commercial drilling is yet to emerge.

\section{Methods}

\subsection{Geographical context: A proposed fracking site in Fermanagh, Northern Ireland}

In 2011, the Department for Enterprise Trade and Investment (Northern Ireland) granted a petroleum licence to Tamboran Resources PTY Ltd. covering an area of $750 \mathrm{~km}^{2}$ in the west of County Fermanagh to explore the viability of fracking (Fig. 1). Tamboran estimated there is potential for up to 2.2 trillion cubic feet of shale gas within the area covered by the licence (Tamboran, 2012). Delivering 50 years of energy security for the whole of Ireland, the company claimed that their $€ 6$ billion investment would create 600 full-time jobs and up to 24,000 indirect jobs, producing up to $Ł 6.9$ billion of tax revenues to Northern Ireland and setting up a community investment fund in Fermanagh of up to Ł2 million a year (Tamboran, 2012). The granting of the licence in 2011 stimulated debate in the media and government and was met with considerable opposition in the Fermanagh area (Hewitt, 2012). Our fieldwork was carried out in 2014 while the development application was being assessed; therefore, the final outcome was not known to interviewees and questionnaire respondents. Since this initial prospect for development, and subsequent lack of exploration due to public opposition, Tamboran has changed ownership and, just in May 2019, put out a new licence application for public consultation (BBC, 2019).

The economy of Fermanagh consists mainly of agriculture and tourism, and is renowned for its scenic beauty. The licence covers an area which is the only cross-border Global Geopark in the world, attracting up to 55,000 visitors per annum, with tourism in Fermanagh contributing Ł86 million to the economy in 2013 (Northern Ireland Statistics and Research Agency, 2014). Sixty-five percent of Fermanagh consists of farmland, and in Northern Ireland the total income from farming isŁ298 million, with

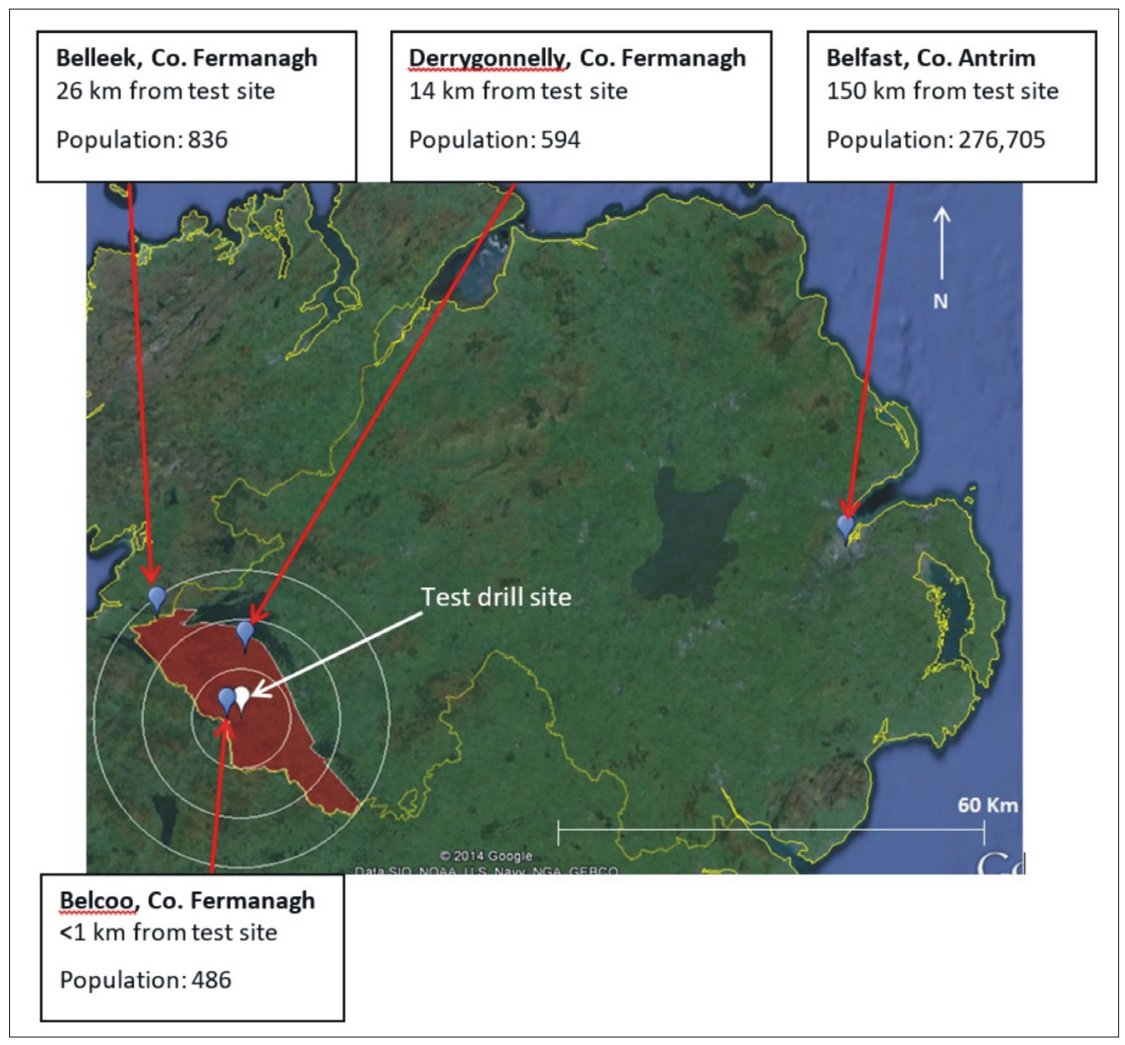

Fig. 1: Map of Northern Ireland with the fracking license area (in red) and the four research sites 
Fermanagh's agricultural sector extensively contributing to the local economy (Department for Agriculture and Rural Development, 2013).

To investigate the relationship between proximity to proposed development and support/opposition, the method described by Warren et al. (2005) was used; sampling the largest centre of population at increasing distances from the site (see Fig. 1). The three sample villages within the licensed area were Belcoo (by test site), Derrygonnelly (14 km from the test site), and Belleek (26 km from the test site). A forth sample, representing more remote, nationallevel perceptions was collected in in Belfast, the largest city of Northern Ireland, some $150 \mathrm{~km}$ away.

\subsection{Questionnaire survey design}

The survey questionnaire was developed using various sources, in particular literature on the possible disadvantages and benefits that fracking can have on the environment, economy, and communities (Stevens, 2010; Smith, 2012; White et al., 2015). The questionnaire began with an introductory section explaining the purpose of the research followed by five sections to understand what people's perceptions of fracking were (in general, and specifically in Fermanagh) and what may govern their perceptions (see Tab. 1). The questionnaire contained a mixture of open-ended, Likert scales, and fixed responses, allowing for a range of answers, and an additional comments section to highlight any important reasons people may have for support or opposition (McLafferty, 2003). The mixture of question types also permitted the quantitative research to be blended with the depth and insights of qualitative inquiry (Kitchin and Tate, 2000).

In the period 15-23 August 2014, the first author conducted thirty questionnaires in each location. Respondents were recruited during the day, in public spaces in the three villages and in Belfast city centre. The questionnaires were conducted on the spot, with either the interviewer asking the questions and filling in the form, or with interviewees reading the questions and filling in the form by themselves if they preferred that.

\subsection{Textual Analysis}

Despite being unable to interview Tamboran, van der Horst and Vermeylen (2012) suggest that the preferences expressed by organisations can be analysed from their communications in the form of press releases, websites, and reports. These forms of communication were analysed along with publications by the Northern Ireland Assembly and the local protest group, FFAN, to understand the policies in place in regards to fracking and the reasons why some groups oppose them.

The media plays a key part in the production of perceptions; therefore; to understand what may influence people's perceptions of fracking, textual analysis was carried out on two local (Fermanagh Herald and The Impartial Recorder) and national newspapers (Belfast Telegraph and Belfast Newsletter). Using the academic database LexisNexis, the term 'fracking' was searched for in the newspapers from $1^{\text {st }}$ April 2011, when the license was first granted, until $1^{\text {st }}$ December 2014, when the judicial review was confirmed. The content of the article was analysed, for example, whether it supported or opposed fracking and the reasons behind these views, to see if there were any differences in the coverage of the conflict. The analysis provided an insight into variations in the representations of fracking in the newspapers and how public perceptions may in turn be shaped by these representations (Evensen et al., 2014; Jaspal and Nerlich, 2014).

\section{Results}

Of the 120 respondents $47 \%$ were male and $53 \%$ female. Respondents ranged in age from 18-75+ years, with the largest proportion in the 35-44 years category (29\%, Median $=37$ years). Fifty-one percent of respondents were in full-time employment with Education (20\%), Tourism (17\%), and Health Services (13\%) being the three largest employment categories.

\subsection{Perceptions of fracking in each location}

Overall, there were high levels of knowledge about fracking; only one respondent had never heard of it and $83 \%$ of all respondents had at least a general knowledge of fracking.

As Figure 2 shows, the highest levels of opposition were found closest to the drilling test site; $97 \%$ of respondents were strongly opposed in Belcoo, 67\% in Derrygonnelly and $43 \%$ in Belleek with only $6 \%$ in Belfast. Levels of support did increase with distance from the proposed test site, however, these supporters remained very low in number with only $13 \%$ of respondents in Belleek supporting fracking in Fermanagh and 27\% strongly supportive in Belfast. This spatial pattern was also seen in regards to fracking in general, as shown in Figure 3. The overall trend

\begin{tabular}{ll}
\hline Section & Information Obtained \\
\hline Introduction & $\begin{array}{l}\text { Detailed the purpose of the research, instructions of how to complete the questionnaire and my } \\
\text { contact details. }\end{array}$ \\
Socio-demographic & Age, gender, qualifications, occupation and employment sector. \\
Psychological (Personal Experience) & $\begin{array}{l}\text { Psychological proximity (measured as length of dwelling at a location [for local communities], or } \\
\text { whether visited it before [for comparison group]). Evidence of any NIMBY responses to fracking - } \\
\text { attitudes to fracking in general and attitudes to fracking in Fermanagh. }\end{array}$ \\
Knowledge and information & $\begin{array}{l}\text { Extent of people's knowledge of fracking and from what sources they obtained this information. } \\
\text { Perceived Impacts }\end{array}$ \\
The perceived advantages and disadvantages that fracking may bring to the environment, \\
economy and community. \\
Psychological (Trust) & Trust in Tamboran and N.I. Assembly to be transparent, fair and act with due diligence. \\
Additional Comments & If people wished to explain any of their answers or thoughts further. \\
\hline
\end{tabular}

Tab. 1: Concepts explored in each section of the questionnaire (Note: The selection of questions was informed by Kyle et al. [2004], Barr [2007], Devine-Wright [2009], Jacquet [2012], and Boudet et al. [2014]) 


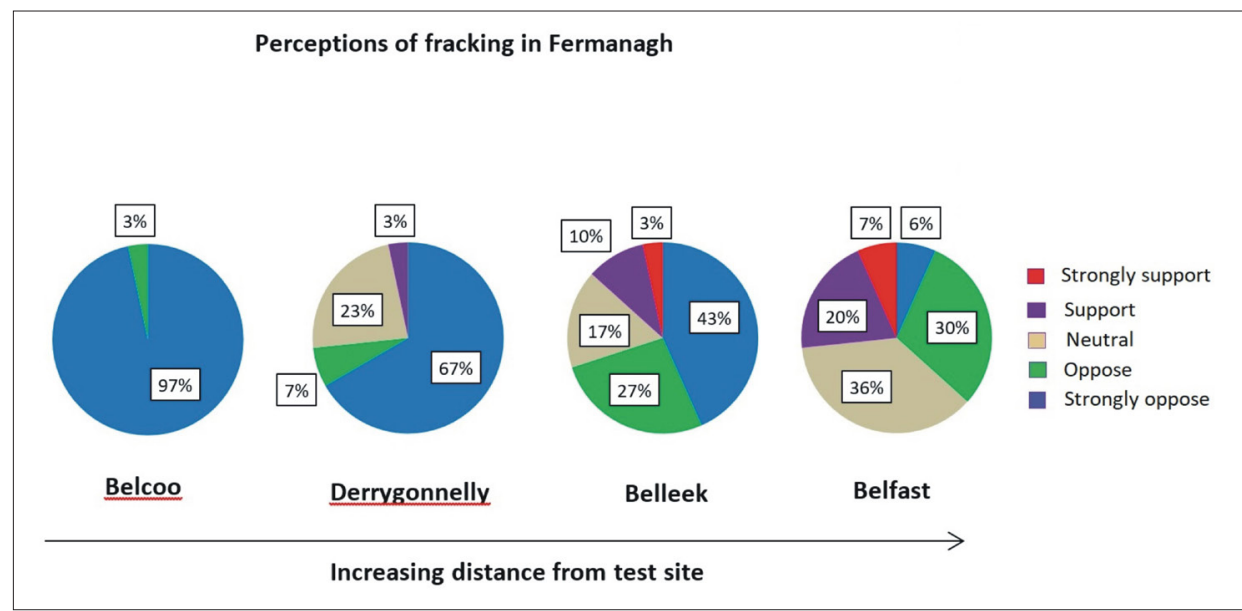

Fig. 2: Perceptions of fracking in the four research sites

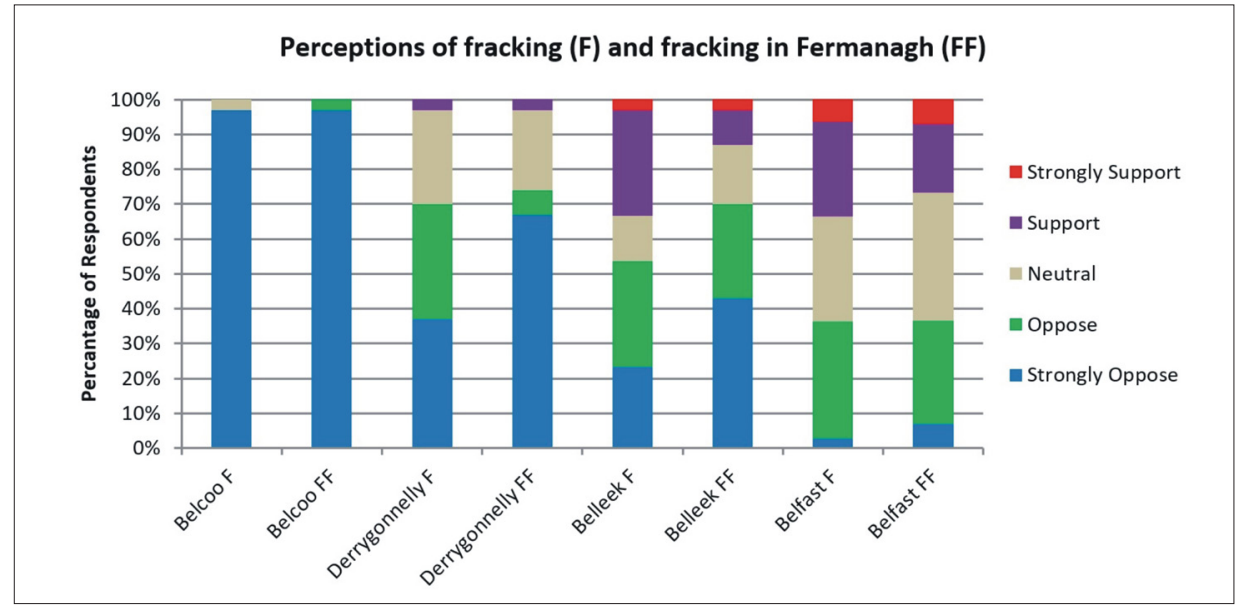

Fig. 3: Perceptions of fracking in general $(F)$ and fracking in Fermanagh $(F F)$ in the four research sites

shows that in all locations respondents were more opposed towards fracking in Fermanagh $(\mathrm{FF})$ than to fracking in general $(\mathrm{F})$ but the distinction diminishes with an increase of distance from the site.

The majority of respondents were opposed fracking, no matter where it was proposed. In Belcoo and Derrygonnelly there was little difference in attitudes towards fracking in general and fracking in Fermanagh. Respondents were more supportive of fracking in general in Belleek, with $33 \%$ either supportive or strongly supportive, however, this reduced to $13 \%$ supportive of fracking in Fermanagh. Belfast had the highest levels of support with $37 \%$ of respondents in favour of fracking in general, however this decreased to $27 \%$ in favour of fracking in Fermanagh, again reflecting that the majority in all locations were less favourable towards the development of fracking in Fermanagh than if it was proposed elsewhere. Both of the above figures demonstrate that opposition to fracking in Fermanagh is highest in the target (local) areas, nevertheless, 37\% of respondents in Belfast were also opposed to fracking in Fermanagh.

\subsection{Perceptions of risks and benefits}

A wide range of risks associated with fracking were identified by respondents, as shown in Figure 4. Risks were identified 759 times across the 120 questionnaires, with respondents in Belcoo identifying the most risks (265 risks identified), and followed by Derrygonnelly (221), Belleek (169) and Belfast (104). A change in the landscape and negative impacts on ecosystems were the most important concerns identified in all four areas, followed by water contamination and hazardous waste materials.

As revealed in Figure 5, in all locations there were considerably fewer benefits identified in comparison to the perceived risks. Benefits were identified 350 times, the most in Belfast (117), which then declined to just 13 identified in Belcoo. Economic benefits were regarded as the most important positive impacts, as well as a potential source of employment, and this was recognised in all locations. Respondents in Belcoo barely associated fracking with having any benefits, compared to those in Belfast; this further exemplifies that distance from the proposed test site had an impact on the formation of perceptions of proposed fracking, although in the opposite direction to the most commonly observed relationship in the United States.

\subsection{Personal experience with Fermanagh: Psychological proximity}

Figure 6 demonstrates that in the three target sites, temporal proximity to Fermanagh (as measured by length of time living there) is related to the level of opposition to proposed fracking. Respondents who lived in Fermanagh for a longer period of time were more likely to oppose proposed fracking than respondents who lived in Fermanagh for fewer years.

Of the respondents who had lived in Fermanagh for over 31 years $(n=38), 97 \%$ were opposed or strongly opposed to fracking. This strong opposition was also seen 


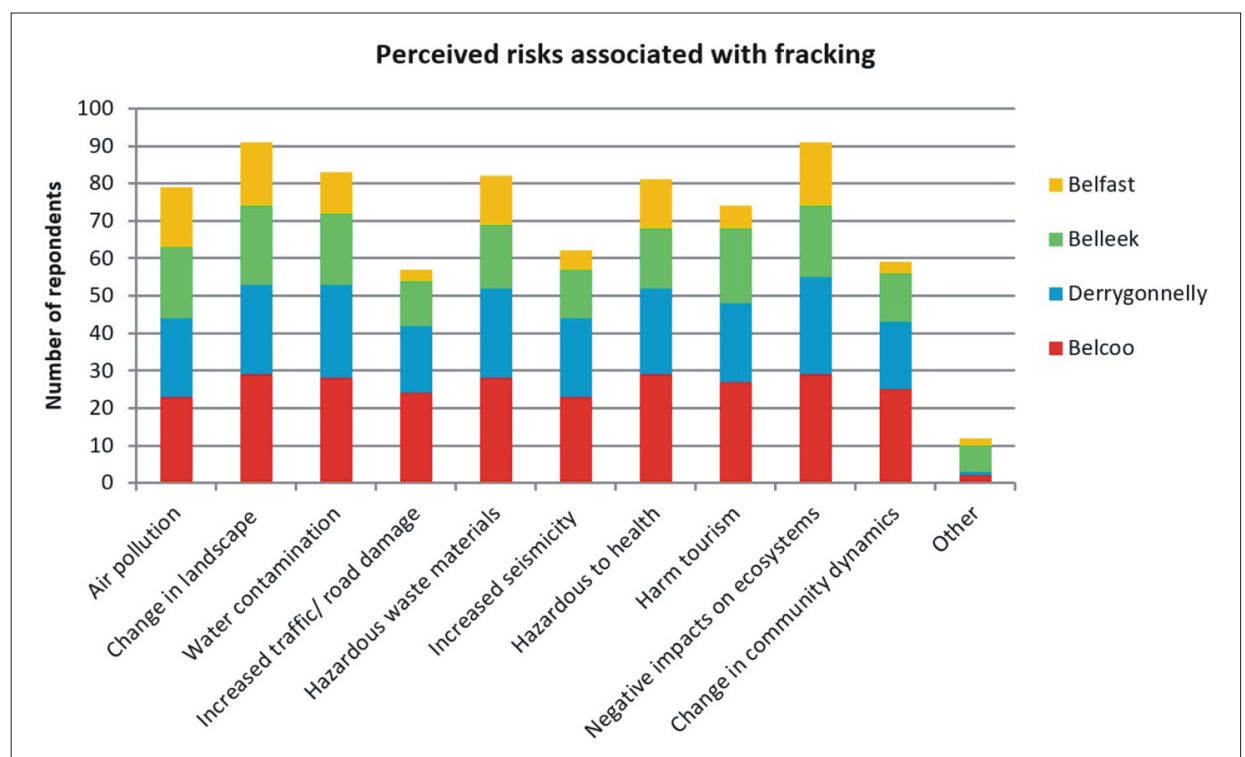

Fig. 4: The main risks respondents associated with fracking

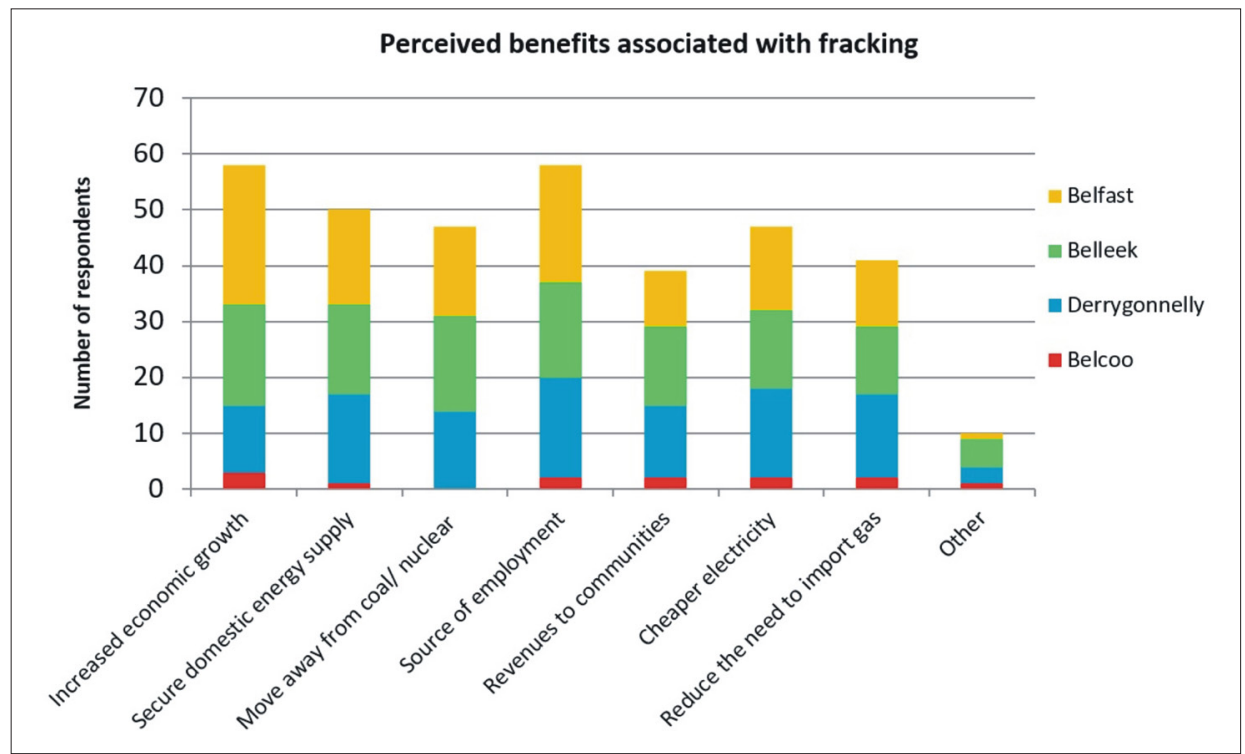

Fig. 5: The main benefits respondents associated with fracking

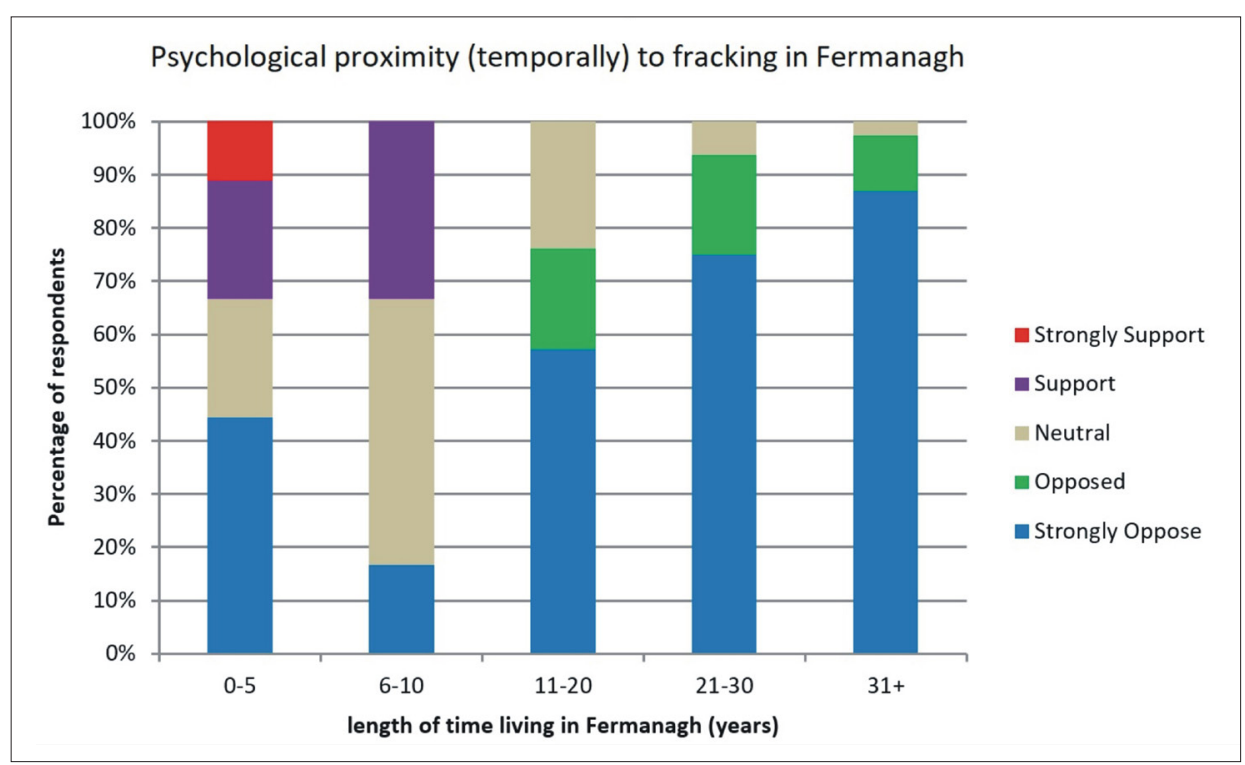

Fig. 6: the relationship between residence time (psychological proximity) and perception of fracking in Fermanah (for respondents from the three local communities, i.e. $N=90$ ) 
in responses by residents who had lived in Fermanagh for 11-20 and 21-30 years $(\mathrm{n}=37)$. As the length of time living in Fermanagh decreased there were increasing levels of support for fracking in Fermanagh, with $33 \%$ of respondents who lived in Fermanagh for less than 10 years ( $\mathrm{n}=15$ ) holding more supportive views of proposed fracking. In Belfast, respondents who had visited Fermanagh before $(\mathrm{n}=21)$ and therefore had personal experience with the area (Kyle et al., 2004; Devine-Wright, 2009), were more opposed to fracking than those who had never visited Fermanagh before $(n=9)$; see Figure 7 . People who had not visited Fermanagh held more supportive views of proposed fracking in Fermanagh, 44\% were in favour compared to $19 \%$ in favour who had personal experience with the area.

\subsection{Trust}

Figure 8 reveals that there were high levels of distrust in the developer, Tamboran, particularly in Belcoo where $100 \%$ of respondents, distrusted or completely distrusted the company. Again, a spatial pattern is seen with levels of trust increasing with distance from the test site, with the highest levels of trust found in Belfast (30\% of respondents). Nevertheless, overall levels of trust remain very low with no respondents completely trusting Tamboran, and only $12 \%$ of all respondents having some trust in them.

Trust in the Northern Ireland Assembly was also found to be very low, with $65 \%$ of all respondents distrusting or completely distrusting the Northern Ireland Assembly to be decisive and engage with all parties involved in the planning process. No relationship was found between distance from the site and levels of trust in the Northern Ireland Assembly.

\subsection{Sources of Information}

There were a wide variety of sources respondents used to obtain information about fracking. The three most used sources in each location are presented in Table 2; individual research on the Internet was a popular source of information in all locations. In Belcoo and Derrygonnelly

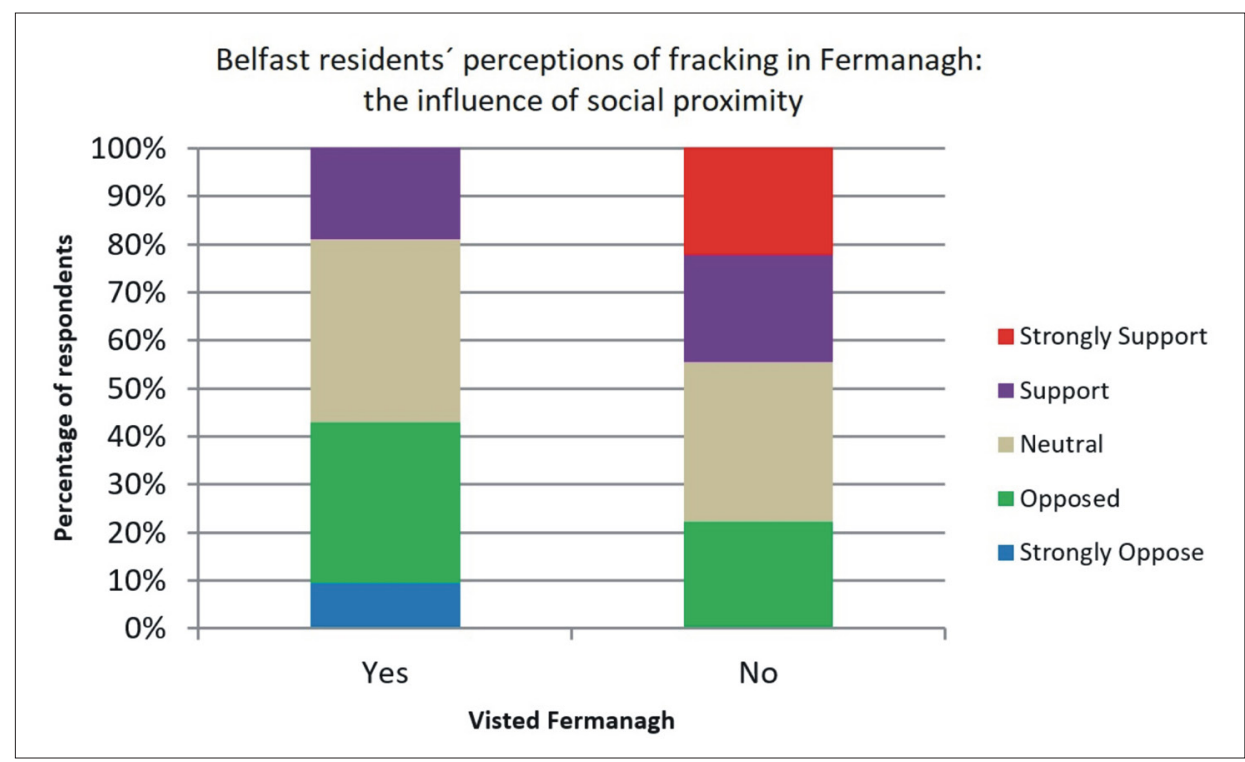

Fig. 7: The relationship between familiarity with Fermanagh through visits (psychological proximity) and perception of fracking in Fermanach (for Belfast respondents, i.e. $N=30$ )

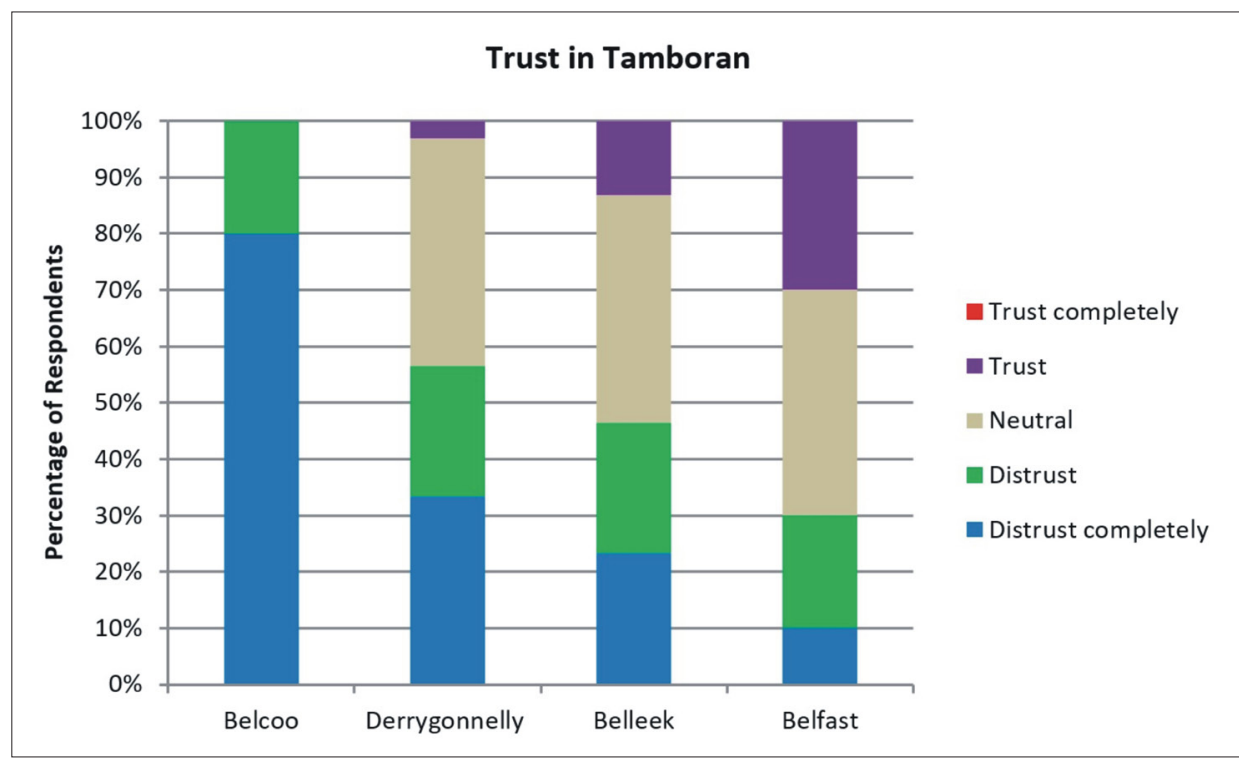

Fig. 8: Trust in the fracking company Tamboran in each of the four research sites 
(the two areas closest to the proposed test site), many respondents obtained information about fracking from local protest groups. This evidence confirms that local protest groups are often trusted and can have a strong impact on local public opinion.

The relationship between obtaining information local protest groups and fracking perceptions can also be seen in Figure 9, with $93 \%$ of respondents who obtained information from them $(\mathrm{n}=46)$ opposed or strongly opposed to fracking in Fermanagh. Those who attended community meetings $(\mathrm{n}=34)$ were also strongly opposed to fracking in Fermanagh. Respondents who were more supportive of fracking gained knowledge from the Internet (own research and social media), the news on television, national newspapers, and a small minority from the local authorities.

Of those respondents who read national newspapers ( $\mathrm{n}=17$ ), $18 \%$ strongly supported fracking, however $44 \%$ were strongly opposed. Readers of the local newspapers $(\mathrm{n}=52)$ were much more likely to hold opposing views with $94 \%$ of respondents who read the local newspaper either opposed or strongly opposed to fracking in Fermanagh.
To see how the content of newspaper articles may have influenced reader's perceptions, textual analysis was conducted on newspaper articles in local and national newspapers that reported about fracking from $1^{\text {st }}$ April 2011 $1^{\text {st }}$ December 2014. In total, the Belfast Telegraph had 121 articles, Belfast Newsletter 31, Impartial Reporter 79 and Fermanagh Herald 56. The majority of articles in all the newspapers were opposed to fracking, particularly in the local newspapers, where $94 \%$ and $88 \%$ of articles were opposed to fracking in the Impartial Reporter and the Fermanagh Herald respectively (Fig. 10). Local newspapers held much more opposing views compared to national newspapers, where articles were more mixed in opinion, with $44 \%$ and $41 \%$ of articles supportive of fracking in the Belfast Telegraph and the Belfast Newsletter. The main reasons cited for support of fracking included economic prosperity and energy security in both national and local newspapers, compared to the difference in the reasons for opposition between the national and local newspapers. National newspapers argued that the negative effect on the environment from pollution and water contamination was a reason to oppose fracking, compared to the local papers that focused on the physical change that could occur to the Fermanagh landscape.

\begin{tabular}{llc}
\hline Location & Sources of Information & Share of respondents (\%) \\
\hline Belcoo & Internet (own research) & 63 \\
& Local Protest Group & 60 \\
\multirow{3}{*}{ Derrygonnelly } & Community Meetings & 57 \\
& Local Newspaper & 60 \\
& Local Protest Group & 53 \\
\multirow{3}{*}{ Belleek } & Internet (own research) & 47 \\
& Local Newspaper & 53 \\
& Internet (own research) & 53 \\
Belfast & Internet (social media) & 50 \\
& News on Television & 53 \\
& National Newspaper & 50 \\
& Internet (own research) & 30 \\
\hline
\end{tabular}

Tab. 2: Summary of the top three sources of information used by people in the four research locations to obtain information about fracking

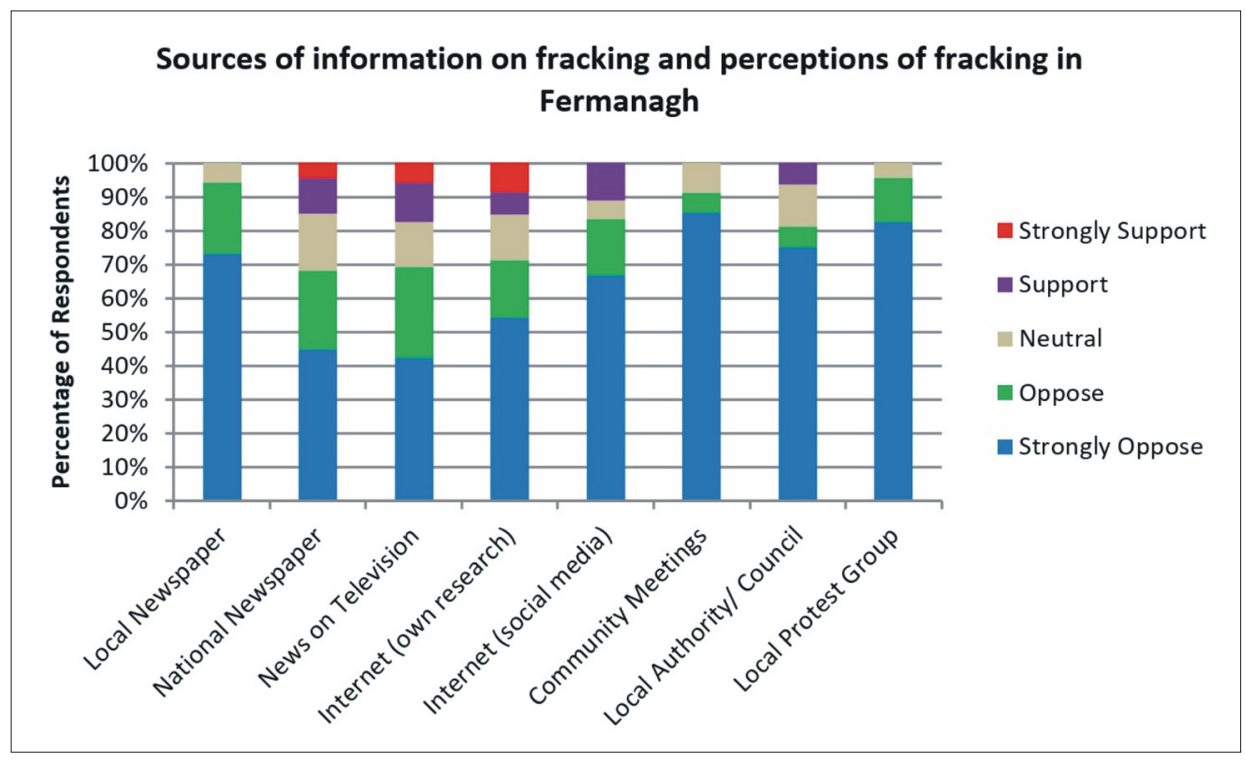

Fig. 9: Respondents' main source of information on fracking, and their own perception of fracking 


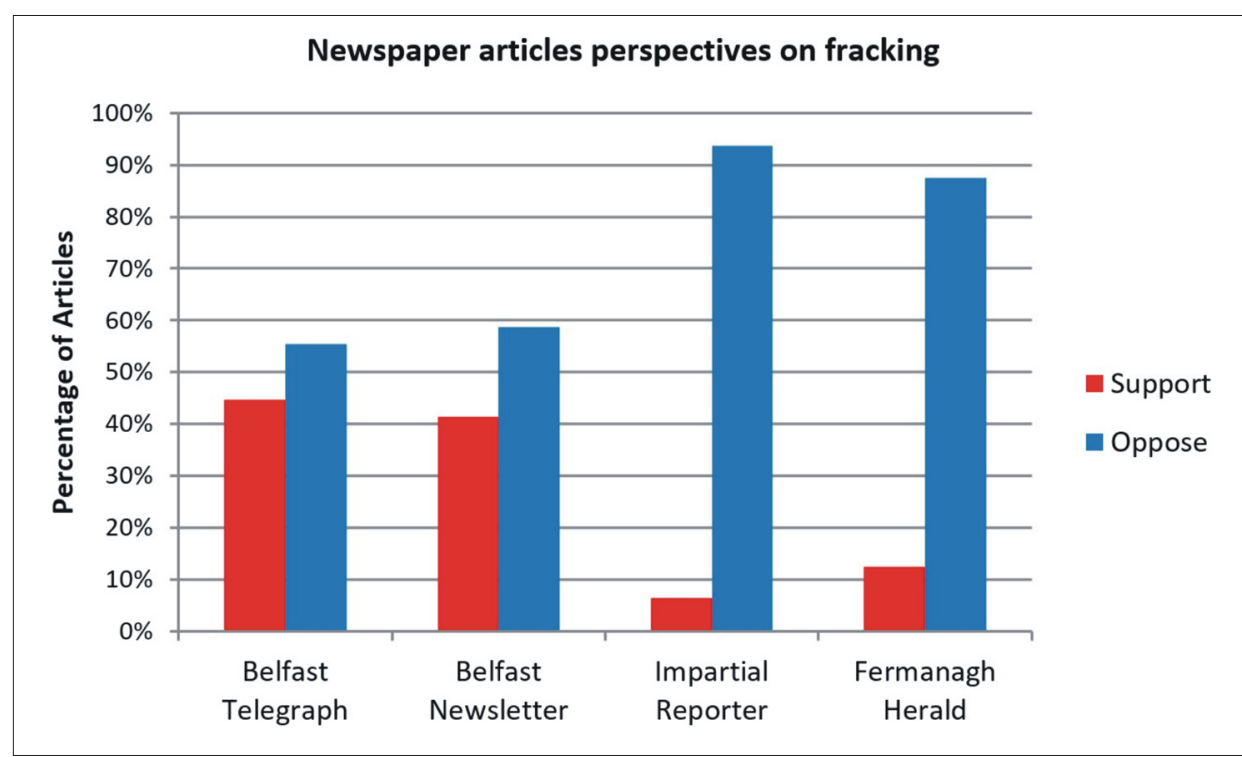

Fig. 10: Number of supportive and critical articles on fracking, reporting in the two national papers (Belfast Telegraph and Belfast Newsletter) and the two local papers in Fermanagh (Impartial Reporter and Fermanagh Herald)

\section{Discussion}

\subsection{Localised opposition}

The results indicate that opposition to fracking in Fermanagh is high, with $70 \%$ of all respondents opposed, much higher levels of opposition than observed in research conducted at a similar time in the UK generally (O'Hara et al., 2012; 2014; Department of Energy and Climate Change, 2014). The results also show clear evidence of a distance decay effect with regards to the strength of the opposition (nearer is stronger). This is consistent with findings from various studies beyond the fracking perceptions literature that residents closer to proposed developments are more likely to be opposed than those who live further away (van der Horst, 2007; van der Horst and Toke, 2010; Schaffer-Boudet, 2011; van der Horst and Vermeylen, 2012). Geographic and psychological proximity are predictors of opposition to fracking in Fermanagh; those in locations closest to proposed development were most likely to identify (multiple) potential risks (Fig. 4).

The small difference in opinions of fracking in general and fracking in Fermanagh, along with the high levels of opposition in all locations (including Belfast) indicates opposition is not just localised; there was a near blanket rejection of the technology. Opposition to fracking in Fermanagh appears to be a case of "not-in-anyone'sbackyard" (Schaffer-Boudet, 2011).

\subsection{Psychological proximity}

Observations from this study support the contentions from construal level theory that temporal, social, and/or spatial proximity to fracking (via connection with the place in which fracking is proposed to occur) will make fracking more concrete and less abstract. Respondents who lived in Fermanagh for over ten years were more opposed to proposed fracking than those who lived in Fermanagh for less than 10 years. Additionally, respondents from Belfast who had visited Fermanagh were more likely to oppose proposed fracking than those who had never been there before (Fig. 7). Whilst the connection between psychological proximity and support/ opposition has been unclear in the United States, it is intuitive that greater proximity (including proximity in time and space) would equate to increased opposition in Northern Ireland, and likely the UK more widely. Whilst local benefits actually exist in some US communities near development, there are no benefits yet in the UK because development does not actually exist currently. Furthermore, even if development were to occur in the UK, the much smaller scale on which development would occur, compared to the US, the lack of privately-owned mineral rights, the higher population densities in the UK, and the different mix of local industries, including tourism, would seem to point in favour of local opposition (Boudet et al., 2016; Junod and Jacquet, 2019).

High levels of efficacy (self-efficacy and collective efficacy) were evident throughout the local communities, with organised protests and community meetings. Many people felt that the conflict actually brought the community together rather than forcing them apart, thereby empowering communities to oppose change (Lewicka, 2011). Given Northern Ireland's sectarian history, this coming together is even more notable. In the open-ended comment portion of our research, some participants reflected:

"Aye it sure has brought the community together with a common goal. We had a cross-community service outside the gates [of the test site] to show Stormont ${ }^{1}$ it is not a sectarian protest. We had Methodists, Catholics, Protestants, Quakers, Baptists, Men, Women, Grandads, Grandsons, you name it, all there to prove that no one wants fracking." (FFAN member, Belcoo)

"I used to just smile and say hello to my neighbour but I went to a meeting about fracking and saw my neighbour there. Since then we've been in lots of contact even making a sign for in front of our houses." (Aoife, Belcoo)

This indicates that communities can be shaped by opposition to proposed facilities, contributing to the reproduction of local identities and collective place attachment (Dalby and Mackenzie, 1997; Manzo and Devine-Wright, 2014).

\footnotetext{
${ }^{1}$ Stormont is the name of the area in Belfast where the Northern Ireland Assembly is based
} 


\subsection{Sources of information}

Respondents in this study were well-informed about fracking and the associated impacts, which contradicts findings from earlier studies (Boudet et al., 2014; DECC, 2014). Respondents used many sources to obtain information about fracking (see Tab. 2), in particular from protest groups who were very active in local areas, which may help explain why there was such high opposition within these localities. Fermanagh Fracking Awareness Network organised meetings, circulated flyers ${ }^{2}$ with information about fracking and its impacts, whilst also encouraging individuals to do their own research. However, the information they provided cannot be considered 'objective', but rather as produced in line with their strong opposing views (MacDonald, 2001).

In line with findings by Jones et al. (2013), opposition groups used communication technologies and social media to good effect, which could explain the high levels of opposition by respondents who used social media to learn about fracking (over 80\% who used social media were opposed to fracking in Fermanagh). Using the Internet has a much higher potential for advocacy, as was recognised by a respondent;

"Fracking has got a bad name due to scare mongering and press interest stirred up by the 'like' culture of Facebook rather than being scientifically based" (Comment on questionnaire in Belfast)

Public awareness has been fuelled by increasing media attention, and this study found that newspapers, both local and national, were highly used sources of information by all respondents (Tab. 2). The majority of articles in both local and national newspapers drew attention to the negative aspects of fracking, in particular environmental aspects with headlines in the Impartial Reporter calling fracking the "geological equivalent of an endoscopy". This negative journalistic style is often summed up as "bad news is good news; good news is no news" for media outlets seeking to share engaging stories (Cohn, 1989, p. 5), which may explain why most newspapers focused on the negative impacts of fracking.

The textual analysis was exploratory, used to illustrate some of the differences between the newspapers (Dixon and Durrheim, 2000), finding that local newspapers (Impartial Reporter and Fermanagh Herald) went beyond the binary divide of economic benefits versus environmental costs that were usually a major point of discussion in the national papers (Belfast Telegraph and Belfast Newsletter). The local newspapers discussed local, social, and personal costs of fracking and its implications for ways of life with headlines such as "Community are Guinea Pigs" (Fermanagh Herald), which could provide an explanation for the high levels of opposition in the local areas where local newspapers were widely used as sources of information about fracking.

National newspapers were more supportive of fracking, and those who were more supportive of fracking were also readers of national newspapers. Articles supportive of fracking cited economic reasons, the Belfast Newsletter referred to shale gas as "Gold beneath our feet", and economic benefits were also the main advantages identified by respondents in this study (Fig. 5). Supporters of fracking in Fermanagh also watched the news on television, which mirrors findings by Boudet et al. (2014) and O'Hara et al. (2014).

\section{Conclusions}

This study has supported the importance of several key factors previously identified as influencing perceptions of fracking. It did so in the novel context of Northern Ireland, in a place where fracking has been proposed, but has not yet occurred. It is to the best of our knowledge the first study to draw together geospatial and psychological proximity, trust, and media use. Our findings show that:

1. Psychological proximity measured through the proxy of geospatial distance has clear influence on perceptions of fracking in Fermanagh; the level of support grows with the increase in spatial distance to the proposed fracking site.

2. Non-spatial aspects of psychological proximity - via longer temporal connection to Fermanagh, or having visited Fermanagh from Belfast, is also influential in the formation of perceptions towards proposed fracking.

3. Perceptions of trust in Tamboran reflect attitudes towards fracking in Fermanagh, with high levels of distrust correlating with high levels of opposition. Trust in the Northern Ireland Assembly was also low but displayed no spatial gradient and did not appear to be linked to perceptions of fracking in Fermanagh.

4. The key source of information reportedly used by the research participants to understand fracking seems to shape (or at least to represent or confirm) perceptions of fracking in Fermanagh. Those who read local newspapers, were in contact with the local protest group, and attended community meetings were very likely to oppose proposed fracking. Meanwhile those who said they obtained their information from reading national newspapers and watching the news on television were more likely to be supportive of fracking in Fermanagh.

Results showed that respondents were relatively wellinformed about fracking, with opposition based strongly upon the psychological proximity to the local place; therefore, this research supports the growing body of literature which suggests that NIMBY theory should be reconceived, and localised opposition is likely founded upon processes of place attachment and place identity. Due to the strong relationship found between perceptions of fracking in general and fracking in Fermanagh, and from interview data, we would be inclined to agree with calls to use "not-inanyone's-backyard" as an explanation for most (but not all) of the public opposition to fracking (Schaffer-Boudet, 2011), as the majority of respondents calling for a blanket rejection of fracking, not just opposing fracking in Fermanagh.

Results from this study demonstrate that to manage effectively siting processes in specific areas, it is critical to understand what influences public support and opposition. Responding carefully to widespread negative public perceptions about fracking will be essential if shale gas is to be commercially exploited in the future (as seems to be Tamboran's renewed focus [BBC, 2019]). It is evident that public attitudes have played a critical role in shaping the degree to which shale gas may, or may not, be developed in Northern Ireland. This research has shown that the public have spoken and "Fermanagh is not for shale". However studies in relation to wind energy have shown how perceptions change over time as development progresses (Devine-Wright, 2005; 2009); therefore, further research

\footnotetext{
${ }^{2}$ Flyers available at: http://www.frackaware.com/wordpress/?page_id=941 Accessed: 20 June 2019
} 
could investigate whether opposition would increase or decrease if fracking had received the green light and commercial drilling had commenced.

The very clear patterns identified in this study despite the relatively humble size of the sample, and the contrasting findings with (and amongst) studies from the United States, show that there are still new insights to be gained from further research into the perceptions of locally new and controversial activities like fracking. That doesn't mean we should necessarily have 'more of the same' research in different locations. It could be argued that the likelihood of uncovering generalizable findings like the (construal level theory) confirmation of a distance decay effect in the support/ opposition to fracking, depends on an individually tailored research design that reflects the particular lie of the land, e.g. the histories and characteristics of local communities, the presence of particular media outlets and the nature of the economic and political landscape.

\section{Acknowledgement}

Dan van der Horst is grateful to acknowledge the support received from the grant project "Exploring social-spatial diffusion of renewable energy projects in the Czech Republic: lessons for adaptive governance of energy transition" (No. 16-04483S), funded by the Czech Science Foundation.

\section{References:}

AITKEN, M. (2010): Power and community benefits: Challenges and opportunities. Energy Policy 38: 6066-6075.

ALCORN, J., RUPP, J., GRAHAM, J. D. (2017): Attitudes toward "fracking": Perceived and actual geographic proximity. Review of Policy Research, 34(4): 504-536.

ALTMAN, I., LOW, S. M. (1992): 'Place Attachment'. New York, Plenum Press.

ASHMOORE, O., EVENSEN, D., CLARKE, C., KRAKOWER, J., SIMON, J. (2016): Regional newspaper coverage of shale gas development across Ohio, New York, and Pennsylvania: Similarities, differences, and lessons. Energy Research \& Social Science, 11: 119-132.

BARR, S. (2007): Factors influencing environmental attitudes and behaviors - A UK case study of household waste management. Environment and Behaviour, 39: $435-473$.

BBC (2019): 'Fracking: Tamboran in new licence bid in Fermanagh' [online]. [cit. 19.06.2019]. Available at: ireland-48191165

https://www.bbc.co.uk/news/uk-northern-

BELL, D., GRAY, T., HAGGETT, C. (2005): Policy, Participation and the social gap in wind farm siting decisions. Environmental Politics, 14: 460-477.

BIO Intelligence Service (2013): Analysis and presentation of the results of the public consultation "Unconventional Fossil Fuels (e.g. Shale Gas) in Europe" Final Report prepared for European Commision. DG Environment [online]. [cit. 16.01.2015]. Available at: http://ec.europa. eu/environment/integration/energy/pdf/Shale\%20 gas\%20consultation_report.pdf

BOUDET, H., BUGDEN, D., ZANOCCO, C., MAIBACH, E. (2016): The effect of industry activities on public support for 'fracking'. Environmental Politics, 25(4): 593-612.
BOUDET, H., CLARKE, C., BUGDEN, D., MAIBACH, E., ROSER-RENOUF, C., LEISEROWITZ, A. (2014): "Fracking" controversy and communication: Using national survey data to understand public perceptions of hydraulic fracturing. Energy Policy, 65: 57-67.

BOUDET, H. S., ZANOCCO, C. M., HOWE, P. D., CLARKE, C.E. (2018): The effect of geographic proximity to unconventional oil and gas development on public support for hydraulic fracturing. Risk Analysis, 38(9): 1871-1890.

BREAKWELL, G. M. (1992): Processes of self-evaluation: efficacy and estrangement. In: Breakwell, G. M. [ed.]: Social Psychology of Identity and the Self-concept. Surrey, Surrey University Press.

BROWN, B. B., PERKINS, D. D. (1992): Disruptions in Place Attachment. In: Altman, I., Low, S. [eds.]: Place Attachment (pp. 279-304). New York, Plenum Press.

CLARK, A., WILFORD, R. (2011): Political Institutions, Engagement and Outreach: The case of the Northern Ireland Assembly. Parliamentary Affairs, 1-24.

CLARKE, C.E., BUGDEN, D., HART, P.S., STEDMAN, R. C., JACQUET, J. B., EVENSEN, D. T., BOUDET, H. S. (2016): How geographic distance and political ideology interact to influence public perception of unconventional oil/natural gas development. Energy Policy, 97: 301-309.

CLARKE, C. E., EVENSEN, D. T., JACQUET, J., STEDMAN, R. C. (2012): Emerging risk communication challenges associated with shale gas development. European Journal of Risk Regulation, 3(3): 424-430.

CLIFFORD, C. N., VALENTINE, G. (2003): Getting started in geographical research. In: Clifford, C. N., Valentine, G. [eds.]: Key Methods in Geography (pp. 3-16). London, Sage.

COHN, V. (1989): News and Numbers: A guide to reporting statistical claims and controversies in health and other fields. Ames, IA, Iowa State University Press.

COPE, M. (2003): Coding Transcripts and Diaries. In: Clifford, N. J. Valentine, G. [eds.]: Key Methods in Geography (pp. 445-459). London, Sage.

CORTINI, M., TRIA, S. (2014): 'Triangulating Qualitative and Quantitative Approaches for the Analysis of Textual Materials: An Introduction to T-Lab', Social science computer review, 32(4): 561-568.

COTTON, M. (2013): Shale Gas-Community Relations: NIMBY or Not? Integrating Social Factors into Shale Gas Community Engagements, Natural Gas \& Electricity, (9): 8-12.

COX, R. (2013): Environmental Communication and the Public Sphere. $3^{\text {rd }}$ ed. California, Sage.

CRANG, M., COOK, I. (2007): Doing Ethnographies. (pp. 60-69). London, Sage.

DALBY, S., MACKENZIE, F. (1997): Reconceptualising local community: environment, identity and threat. Area, 29: 99-108.

DAVIS, C., FISK, J.M. (2014): Energy Abundance or Environmental Worries? Analyzing Public Support for Fracking in the United States. Review of Policy Research, 31(1): 1-16 
DEAR, M. (1992): Understanding and overcoming the NIMBY syndrome. Journal of the American Planning Association, 58(3): 288.

Department of Agriculture and Rural Development (2013) Statistical Review of Northern Ireland Agriculture 2013 [online]. [cit. 07.12.2014]. Availabale at: http://www. dardni.gov.uk/stats-review-2013.pdf.pdf

Department of Energy and Climate Change (2011): Planning our electric future: a white paper for secure, affordable and low-carbon electricity. Crown Copyright [online]. [cit. 18.01.2015]. Available at: https://www.gov.uk/ government/uploads/attachment_data/file/48129/2176emr-white-paper.pdf

Department of Energy and Climate Change (2013): About shale gas and hydraulic fracturing [online]. [cit. 02.06.2014]. London, Crown Copyright. Available at: https://www.gov. uk/oil-and-gas-onshore-exploration-and productioned

Department of Energy and Climate Change (2014): DECC Public Attitudes Tracker - Wave 10. Summary of Key Findings. Crown Copyright [online]. [cit. 16.01.2015]. Available at: https://www.gov.uk/government/statistics/ public-attitudes-tracking-survey-wave-10 Department of Enterprise Trade and Investment (2011) Petroleum Licence, Tamboran Resources PTY LTD, Lough Allen Basin-North [online]. [cit. 07.12.2014]. Available at: http://www.detini.gov.uk/pl2-10_tamboran_original_ licence_document.pdf

DEVINE-WRIGHT, P. (2005) Beyond NIMBYism: towards an integrated framework for understanding public perceptions of wind energy. Wind Energy, 8(2): 125-139.

DEVINE-WRIGHT, P. (2009): Rethinking NIMBYism: The Role of Place Attachment and Place Identity in Explaining Place-protective Action (English). Journal of community \& applied social psychology, 19(6): 426-441.

DEVINE-WRIGHT, P., HOWES, Y. (2010): Disruption to place attachment and the protection of restorative environments: A wind energy case study. Journal of Environmental Psychology, 30(3): 271-280.

DIXON, J., DURRHEIM, K. (2000): Displacing placeidentity: a discursive approach to locating self and other. British Journal of Social Psychology, 39(1): 27-44.

DRIEDGER, S. M. (2007): Risk and the media: a comparison of print and televised news stories of a Canadian drinking water risk event. Risk Analysis. 27: 775-786.

ELLIS, G., COWELL, R., SHERRY-BRENNAN, F., STRACHAN, P. A., TOKE, D. (2013): Planning, energy and devolution in the UK, TPR. Town Planning Review, 84(3): 397-410.

ERWIN, A. (2014): Fracking Firm Tamboran to sue Stormont departments over thwarted Fermanagh drilling plans. Belfast Telegraph [online]. [cit.19.11.2014]. Available at: http://www.belfasttelegraph.co.uk/news/northernireland/fracking-firm-tamboran-to-sue-stormontdepartments-over-thwarted-fermanagh-drillingplans-30757856.html

EVENSEN, D. T., ClARKE, C. E., STEDMAN, R. C (2014): A New York or Pennsylvania state of mind: social representations in newspaper coverage of gas development in the Marcellus Shale. Journal of Environmental Studies and Sciences, 4(1): 65-77.
EVENSEN, D., STEDMAN, R. (2018): Fracking': Promoter and destroyer of 'the good life. Journal of Rural Studies, 59: $142-152$.

EVENSEN, D., STEDMAN, R. (2016): Scale matters: Variation in perceptions of shale gas development across national, state, and local levels. Energy research \& social science, 20: 14-21.

FLYNN, R., BELLABY, P. (2007): Risk and the public acceptance of new technologies [online]. [cit. 12.03.2015]. Available at: http://www.palgraveconnect.com/pc/ doifinder/10.1057/9780230591288

FREUDENBERG, W. R., PASTOR, S. K. (1992): NIMBYS and LULUs: Stalking the syndromes. Journal of Social Issues 48: 39-61.

Geological Survey of Northern Ireland (2012): Regulation of shale gas exploration in County Fermanagh. Report to the Committee of Enterprise, Trade and Investment, $21^{\text {st }}$ June 2012.

GRAVELLE, T. B., LACHAPELLE, E. (2015): Politics, proximity and the pipeline: Mapping public attitudes toward Keystone XL. Energy Policy, 83: 99-108.

GROSS, C. (2007): Community perspectives of wind energy in Australia; the application of a justice and fairness framework to increase social acceptance. Energy Policy, 35: 2727-2736.

HAGGERTY, J. H., KROEPSCH, A. C., WALSH, K. B., SMITH, K. K., BOWEN, D. W. (2018): Geographies of impact and the impacts of geography: unconventional oil and gas in the American West. The Extractive Industries and Society, 5(4): 619-633.

HAGGETT, C., TOKE, D. (2006): Crossing the Great Divide Using Multi-method Analysis to Understand Opposition to Windfarms. Public Administration, 84(1): 103-120.

HANNIGAN, J. A. (1995): Environmental Sociology : a social constructionist perspective. London, Routledge.

HAY, I. (2003): Ethical Practice in Geographical Research. In: Clifford, N. J. Valentine, G. [eds.]: Key Methods in Geography (pp. 37-53). London, Sage.

HEDDING, K. J. (2017): Sources and framing of fracking: A content analysis of newspaper coverage in North Carolina, New York, and Pennsylvania. Environmental Communication, 11(3): 370-385.

HENDERSON, J. A., DUGGAN-HAAS, D. (2014): Drilling into controversy: the educational complexity of shale gas development. Journal of Environmental Studies and Sciences, 4(1): 87-96.

HEWITT, N. J. (2012): The fracking debate - a local viewpoint. International Journal of Ambient Energy, 33(3): 107.

HOLLOWAY, M. D., RUDD, O. (2013): Fracking: The Operations and Environmental Consequences of Hydraulic Fracturing. Beverly MA, Scrivener Publishing.

HUTH, N. I., COCKS, B., DALGLIESH, N., POULTON, P. I., MARINONI, O., GARCIA, J. N. (2018): Farmers' perceptions of coexistence between agriculture and a large-scale coal seam gas development. Agriculture and Human Values, 35: 11-115.

JACQUET, J. B. (2014): Review of risks to communities from shale energy development. Environmental science \& technology, 48(15): 8321-8333. 
JACQUET, J. B. (2012): Landowner attitudes toward natural gas and wind farm development in northern Pennsylvania, Energy Policy, 50: 677-688.

JACQUET, J. B., JUNOD, A. N., BUGDEN, D., WILDERMUTH, G., FERGEN, J. T., JALBERT, K., GLENNA, L. (2018): A decade of Marcellus Shale: Impacts to people, policy, and culture from 2008 to 2018 in the Greater Mid-Atlantic region of the United States. The Extractive Industries and Society, 5(4): 596-609.

JACQUET, J. B., STEDMAN, R.C. (2014): The risk of social-psychological disruption as an impact of energy development and environmental change. Journal of Environmental Planning and Management, 57(9): 1285-1304.

JASPAL, R., NERLICH, B. (2014): Fracking in the UK press: Threat dynamics in an unfolding debate. Public Understanding of Science, 23(3): 348-363.

JASPAL, R., NERLICH, B., LEMAŃCYZK, S. (2014a): Fracking in the Polish press: Geopolitics and national identity. Energy Policy, 74: 253-261.

JASPAL, R., TURNER, A., NERLICH, B. (2014b) Fracking on YouTube: Exploring Risks, Benefits and Human Values. Environmental Values, 23(5): 501-527.

JAY, A. (2005): Not in our Backyard: How to Run a Protest Campaign and Save the Neighbourhood. Devon, White Ladder Press.

JONES, P., HILLIER, D., COMFORT, D. (2013): Fracking and public relations: rehearsing the arguments and making the case. Journal of Public Affairs, 13(4): 384-390.

JUNOD, A. N., JACQUET, J. B. (2019): Shale gas in coal country: Testing the Goldilocks Zone of energy impacts in the western Appalachian range. Energy Research \& Social Science, 55: 155-167.

JUNOD, A. N., JACQUET, J. B., FERNANDO, F., FLAGE, L. (2018): Life in the goldilocks zone: perceptions of place disruption on the periphery of the Bakken Shale. Society \& natural resources, 31(2): 200-217.

KITCHIN, R., TATE, N. J. (2000): Conducting Research in Human Geography: Theory, Methodology and Practice. Harlow, Prentice Hall.

KORPELA, K. M. (1989): Place-identity as a product of environmental self-regulation. Journal of Environmental Psychology, 9(3): 241-256.

KRIMSKY, S. (2007): Risk communication in the internet age: The rise of disorganised skepticism. Environmental Hazards, 7: 157-164

KROHN, S., DAMBORG, S. (1999): On public attitudes towards wind power, Renewable Energy, 16: 954-960.

KYLE, G., BRICKER, K., GRAEFE, A., WICKHAM, T. (2004): An examination of recreationist's' relationships with activities and settings. Leisure Sciences, 26: 123-142.

LACHAPELLE, E., KISS, S., MONTPETIT, É. (2018): Public perceptions of hydraulic fracturing (Fracking) in Canada: Economic nationalism, issue familiarity, and cultural bias. The Extractive Industries and Society, 5(4): 634-647.

LAI, P. H., LYONS, K. D., GUDERGAN, S. P., GRIMSTAD, S. (2017): Understanding the psychological impact of unconventional gas developments in affected communities. Energy Policy, 101: 492-501.
LEONARD, M. (2003): Interviews. In: Miller, R. L., Brewer, J. D. [eds.]: The A-Z of Social Research. London, Sage.

LEWICKA, M. (2010): 'What makes neighbourhood different from home and city? Effects of place scale on place attachment. Journal of Environmental Psychology, 30: $35-51$.

LEWICKA, M. (2011): Place Attachment: How far have we come in the last 40 years. Journal of Environmental Psychology, 31: 207-230.

LONGHURST, R. (2003): Semi-structured interviews and focus groups. In: Clifford, N. J. Valentine, G. [eds.]: Key Methods in Geography (pp. 117-132). London, Sage.

LUKE, H., BRUECKNER, M., EMMANOUIL, N. (2018a). Unconventional gas development in Australia: A critical review of its social license. The Extractive Industries and Society, 5(4):648-662.

LUKE, H., RASCH, E. D., EVENSEN, D., KÖHNE, M. (2018b): Is 'activist' a dirty word? Place identity, activism and unconventional gas development across three continents. The Extractive Industries and Society, 5(4): 524-534.

MACDONALD, K. (2001): Using Documents. In: Gilbert, G. [ed.]: Researching Social Life (pp. 196-211). London, Sage.

MANZO, L. C., DEVINE-WRIGHT, P. (2014): Place attachment: advances in theory, methods and applications. London, Routledge.

MANZO, L. C., PERKINS, D. D. (2006): Finding common ground: The importance of place attachment to community participation and planning. Journal of Planning Literature, 20(4): 335-350.

MAYER, A. (2016): Risk and benefits in a fracking boom: Evidence from Colorado. The Extractive Industries and Society, 3(3): 744-753.

MCLAFFERTY, S. L. (2003): Conducting Questionnaire Surveys. In: Clifford, N. J., Valentine, G. [eds.]: Key Methods in Geography (pp. 77-89). London, Sage.

MCNAUGHT, C., KAY, D., HILL, N., JOHNSON, M., HAYDOCK, H., DORAN, M. (2013): Envisioning the Future- Considering Energy in Northern Ireland to 2050. Department of Enterprise, Trade and Investment (DETI) and Ricardo-AEA.

MENG, Q. (2015): Spatial analysis of environment and population at risk of natural gas fracking in the state of Pennsylvania, USA. Science of the Total Environment, 515: 198-206.

MENG, Q., ASHBY, S. (2014): Distance: A critical aspect for environmental impact assessment of hydraulic fracking. The Extractive Industries and Society, 1(2): 124-126.

MORGAN, D. L. (1997): Focus Groups as Qualitative Research. $2^{\text {nd }}$ ed. London, Sage.

MORROW, D. (2001): The elusiveness of trust. Peace Review 13: $13-19$

MUMFORD, J., GRAY, D. (2010): Consumer engagement in alternative energy - Can the regulators and suppliers be trusted?. Energy Policy, 38(6): 2664-2671.

NERB, J., SPADA, H., LAY, K. (2001): Environmental Risk in the Media: modelling the reactions of the audience. Research in Social Problems and Public Policy, 9: 57-85. 
Northern Ireland Statistical Research Agency (2014): Local Government District Tourism Statistics 2013 [Online]. [cit. 07.12.2014]. Available at: http://www.detini.gov.uk/ lgd_publication_2011-2013.pdf?rev=0

ODAGIU, A., OROIAN, I. G., MIHĂIESCU, T., PAULETTE, L., MIHĂIESCU, R., FLESERIU, A. (2013): Is Hydraulic Fracturing a Threat for Drinking Water Resources?. ProEnvironment Promediu, 6(13): 89-92.

OWENS, S. (2004): Siting, sustainable development and social priorities. Journal of Risk Research, 7(2): 101-114.

O'BRIEN, G., HOPE, A. (2010): Localism and energy: Negotiating approaches to embedding resilience in energy systems. Energy Policy, 38(12): 7550-7558.

O'HARA, S., HUMPHREY, M., JASPAL, R., NERLICH, B., KNIGHT, W. (2014): Public Perception of Shale Gas Extraction in the UK: Has Balcombe bottomed out? Nottingham University Shale Gas Survey [online]. [cit. 23.01.2015]. Available at: Nottingham University Shale Gas Survey Available at: https://www.scribd.com/ doc/131787519/public-perceptions-of-shale-gas-in-theUK-September-2014-pdf

O'LEARY, R. (2003): Correlation and regression. In: Miller, R. L., Brewer, J. D. [eds.]: The A-Z of Social Research. London, Sage.

OLIVE, A. (2016): What is the fracking story in Canada? The Canadian Geographer/Le Géographe canadien, 60(1): 32-45.

PEREIRA, A. (2011): Shale Gas a UK Energy Miracle? Kegworth, Institute of Gas Engineers and Managers.

PERRY, S. L. (2012): Development, Land Use, and Collective Trauma: The Marcellus Shale Gas Boom in Rural Pennsylvania. Culture, Agriculture, Food and Environment, 34(1): 81-92.

PIJAWKA， K. D., MUSHKATEL， A. H. (1991): Public opposition to the siting of the high-level nuclear waste repository: The importance of trust. Policy Studies Review, 10(4): 180-194.

PROSHANSKY, H. M. (1978): The city and self-identity. Environment \& Behaviour, 10(2): 147.

PUTNAM, R.D. (1993): Making Democracy Work: Civic Traditions in Modern Italy. Princeton, Princeton University Press.

RABE, B. G., BORICK, C. (2011): Fracking for natural gas: Public opinion on state policy options. The Center for Local, State, and Urban Policy, Gerald R. Ford School of Public Policy at the University of Michigan.

RAYMOND, C. M., BROWN, G., WEBER, D. (2010): The measurement of place attachment: Personal, community, and environmental connections. Journal of Environmental Psychology, 30(4): 422-434.

RAYNER, S. (2010): Trust and the transformation of energy systems. Energy Policy, 38(6): 2617-2623.

RITCHIE, H., LLOYD, G., GRIFFITHS, P. (2014): A fracking good time? A planned approach to energy resilience in the UK and Ireland. Paper presented to the Association of European Schools of Planning Annual Congress 2014. University of Utrecht and University of Delft.

ROSENBERG, A.A., PHARTIYAL, P., GOLDMAN, G., BRANSCOMB, L. M. (2014): Exposing fracking to sunlight. Issues in Science and Technology (pp. 74-79). Dallas, University of Texas.

Royal Society (2012): Shale gas extraction in the UK: a review of hydraulic fracturing. London, The Royal Society and the Royal Academy of Engineering [online]. [cit. 02.06.2014]. Available at: royalsociety.org/policy/ projects/shale-gas-extraction

SANGARAMOORTHY, T., JAMISON, A. M., BOYLE, M. D., PAYNE-STURGES, D. C., SAPKOTA, A., MILTON, D. K., WILSON, S. M. (2016): Place-based perceptions of the impacts of fracking along the Marcellus Shale. Social Science \& Medicine, 151: 27-37.

SCHAFFER BOUDET, H. (2011): From NIMBY to NIABY: regional mobilization against liquefied natural gas in the United States. Environmental Politics, 20(6): 786-806.

SCHAFFT, K. A., BIDDLE, C. (2015): Opportunity, ambivalence, and youth perspectives on community change in Pennsylvania's Marcellus Shale region. Human Organization, 74(1): 74.

SLACK, B. (2013): Environmental fracturing vs. fracking: while 'fracking' is the subject of much contention in political and social arenas, environmental fracturing continues to make quiet headway. Pollution Engineering, 45(9): 18-24.

SMITH, F. M., FERGUSON, D. P. (2013): Fracking Democracy: issue of management and locus of policy decision making in the Marcellus Shale gas drilling debate. Public relations Review, 39: 377-386.

SMITH, T. (2012): Environmental Considerations of Shale Gas Development. Chemical Engineering Progress, 108(8): 53.

STAMFORD, L., AZAPAGIC, A. (2014): Life cycle environmental impacts of UK shale gas. Applied Energy, 134: 506-518.

STEDMAN, R. (2002): Toward a social psychology of place: Predicting behaviour from place-based cognitions, attitude, and identity. Environment and Behaviour, 34: 561-581.

STEVENS, P. (2010): The 'shale gas revolution': hype and reality. London, Chatham House [online]. [cit. 20.06.2019]. Available at: http://www.chathamhouse.org/sites/default/ files/public/Research/Energy,\%20Environment\%20 and\%20Development/r_0910stevens.pdf

TAMBORAN (2012): Ł6bn Gas Investment Could Create 600 Full Time Jobs and Deliver Security of Supply in Northern Ireland for up to 50 years. Press Release, 31 January 2012.

TAN, H., XU, J., WONG-PARODI, G. (2019): The politics of Asian fracking: Public risk perceptions towards shale gas development in China. Energy Research \& Social Science, 54: 46-55.

TAYLOR, R.W. (2014): Taking sides: clashing views on sustainability. $2^{\text {nd }}$ Ed. New York, McGraw-Hill.

THEODORI, G. L. (2018): Shale energy development in the Southern United States: a review of perceived and objective social impacts. The Extractive Industries and Society, 5(4): 610-618.

UPRETI, B. R., VAN DER HORST, D. (2004): National renewable energy policy and local opposition in the UK: the failed development of a biomass electricity plant. Biomass and Bioenergy, 26(1): 61-69. 
VAN DER HORST, D. (2007): NIMBY or not? Exploring the relevance of location and the politics of voiced opinions in renewable energy siting controversies. Energy Policy, 35(5): 2705-2714.

VAN DER HORST, D., TOKE, D. (2010): Exploring the landscape of wind farm developments; local area characteristics and planning process outcomes in rural England. Land Use Policy 27: 214-221.

VAN DER HORST, D., VERMEYLEN, S. (2012): Ownership claims, valuation practices, and the unpacking of energylandscape conflicts. International Review of Sociology, 22(3): 429-445.

WALKER, G., DEVINE-WRIGHT, P., HUNTER, S., HIGH, H., EVANS, B. (2010): Trust and community: Exploring the meanings, contexts and dynamics of community renewable energy. Energy Policy, 38(6): 2655-2663.

WARREN, C. R., MCFADYEN, M. (2010): Does community ownership affect public attitudes to wind energy? A case study from south-west Scotland. Land Use Policy, 27: 204-213.

WARREN, C. R., LUMSDEN, C., O'DOWD, S., BIRNIE, R. V. (2005): Green on Green: Public perceptions of wind power in Scotland and Ireland. Journal of Environmental Planning \& Management, 48(6): 853-875.

WESTER-HERBER, M. (2004): Underlying concerns in landuse conflicts - the role of place-identity in risk perception. Environmental Science \& Policy, 7(2): 109-116.

WHITE, E., FELL, M., SMITH, L., KEEP, M. (2015): Shale gas and fracking. House of Commons Library Research Paper. $5^{\text {th }}$ February 2015 [online]. [cit. 08.02.2014]. Available at: www.parliament.uk/briefing-papers/sn06073.pdf
WHITMARSH, L., NASH, N., UPHAM, P., LLOYD, A., VERDON, J. P., KENDALL, J. M. (2015): UK public perceptions of shale gas hydraulic fracturing: The role of audience, message and contextual factors on risk perceptions and policy support. Applied Energy, 160: 419-430.

WILLOW, A. J. (2014): The new politics of environmental degradation: un/expected landscapes of disempowerment and vulnerability. Journal of Political Ecology, 21(1): 237-257.

WILLOW, A. J., ZAK, R., VILAPLANA, D., SHEELEY, D. (2014): The contested landscape of unconventional energy development: a report from Ohio's shale gas country. Journal of Environmental Studies and Sciences, 4(1): 56-64.

WOODS, M. (2003): Deconstructing rural protest: the emergence of a new social movement. Journal of Rural Studies, 19(3): 309-325.

WYNNE, B. (2006): Public engagement as a means of restoring public trust in science - hitting the notes, but missing the music?. Community Genetics, 9(3): 211-220.

YUAN, J-L., DENG, J-G., TAN, Q., YU, B-H., JIN, X-C. (2013): Borehole Stability Analysis of Horizontal Drilling in Shale Gas Reservoirs. Rock Mechanics and Rock Engineering, 46(5): 1157-1164.

ZANOCCO, C., BOUDET, H., CLARKE, C. E., HOWE, P. D. (2019): Spatial Discontinuities in Support for Hydraulic Fracturing: Searching for a "Goldilocks Zone". Society \& Natural Reso.

\section{Please cite this article as:}

CRAIG, K., EVENSEN, D., VAN DER HORST, D. (2019): How distance influences dislike: Responses to proposed fracking in Fermanagh, Northern Ireland. Moravian Geographical Reports, 27(2): 92-107. Doi: 10.2478/mgr-2019-0008. 